\title{
ANAK DAN KEJAHATAN (FAKTOR PENYEBAB DAN PERLINDUNGAN HUKUM)
}

\author{
Ria Juliana* dan Ridwan Arifin \\ Fakultas Hukum Universitas Negeri Semarang \\ Gunungpati, Semarang, Jawa Tengah, 50229 \\ Email: riajuliana0910@gmail.com
}

\begin{abstract}
The State of Indonesia has never been separated from existing regulations, given that the State of Indonesia is a rule of law and all actions taken refer to the applicable law. The problem of a law lies in the procedure for the application of the law and the implementation of the law, in legal protection for children in Indonesia, both victims and perpetrators have the right to be protected, for this reason a rule of law has been set against the child's own misconduct applicable. Problematics of arrest and detention and punishment of crimes committed by children enactment of article 43 of Act No. 3 of 1997 which explains that child detainees are basically still in effect the provisions of the Criminal Procedure Code (KUHAP) are the loss of children's rights and protection against applicable law. The development of the rights of the child is a public concern because at this time child perseverance has spread and the application of the law continues to apply to that the rights of children must also be considered to see that children's rights must also be fought for. Above everything discussed above that neglected the rights of children and their protection was due to the lack of attention from parents and families and a small part of this resulted from an environment that was not good for the character of the child himself. To create high peace and stability then the basis of the change is parents. Improvements made to the guidance of children that are carried out fundamentally with love and love, it does not rule out the possibility of child delinquency or criminal acts that are done less, other things if the child is allowed to grow without attention then does not rule out the greater the crime that will be committed.
\end{abstract}

Keywords: Protection, Children's Rights, Crime, Criminal Law

\begin{abstract}
Negara Indonesia tidak pernah terlepas dari peraturan yang sudah ada, mengingat bahwa Negara Indonesia adalah Negara hukum maka segala tindakan yang dilakukan merujuk pada hukum yang berlaku. Problematika suatu hukum tersebut terletak pada tatacara penerapan hukum dan pengimplementasian hukum tersebut,dalam perlindungan hukum terhadap anak di Indonesia,baik korban dan pelaku tindak pidana memliki hak untuk dilindungi, untuk itu sebuah aturan hukum telah ditetapkan terhadap tindakan kenakalan anak itu sendiri yang dianggap melanggar aturan yang berlaku.Problematika penangkapan serta penahanan dan hukuman terhadap kejahatan yang dilakukan anak berlakunya pasal 43 Undang Undang Nomor 3 Tahun 1997 yang menjelaskan bahwa penangkapa anak pada dasarnya masih diberlakukanya ketentuan KUHAP (Kitab Undang-Undang Hukum Acara Pidana) adalah hilangnya Hak-hak anak dan perlindungannya terhadap hukum yang berlaku. Pengembangan hak-hak atas anak tersebut menjadi perhatian public karena pada saat ini kenekalan anak telah menyebarluas dan penerapan hukum terus berlaku untuk itulah hak-hak atas anak juga harus diperhatikan melihat bahwa hak-hak anak juga harus diperjuangkan. Diatas segala yang dibahas diatas bahwa yang menyebabkan hak-hak anak dan perlindungannya terabaikan hal tersebut dikarenakan akibat perhatian orangtua maupun keluarga yang kurang dan sebagian kecil hal tersebut diakibatkan dari lingkungan yang tidak baik bagi karakter anak itu sendiri.Untuk menciptakan ketentraman dan stabilitas yang tinggi maka yang menjadi dasar perubahnya adalah orangtua.Perbaikan yang dilakukan terhadap pembinaan anak yang dilakukan mendasar dengan kasih sayang dan cinta hal tersebut tidak menutup kemungkinan kenakalan anak atau tindak pidana yang dilakukan semakin berkurang,lain halnya jika anak tersebut dibiarkan tumbuh tanpa adanya perhatian maka tidak menutup kemungkinan semakin besar tindak pidana yang akan dilakukan.
\end{abstract}

Kata Kunci: Perlindungan, Hak-Hak Anak, Kejahatan, Hukum Pidana 


\section{Pendahuluan}

Anak adalah generasi selanjutnya yang berpotensi untuk mengubah Negara Indonesia menjadi Negara yang lebih maju untuk itu anak sering juga disebut sebagai generasi penerus bangsa di hari mendatang yang berperan penting dalam menentukan sejarah bangsa dan Negara serta hidup suatu bangsa di masa yang akan datang. Namun pada dasarnya perkembangan kejiwaan anak tidak sama dengan orang dewasa untuk itulah pendidikan sangat berperan sebagai pembentuk karakter anak.

Proses perkembangan karakter anak tersebut secara umum terdiri dari tiga fase yaitu; Fase Pertama disebut sebagai masa anak kecil, fase kedua disebut sebagai masa kanak-kanak dan fase ketiga disebut masa remaja/pubertas. Dari fase tersebut maka akan terbentuk karakter anak yang sesuai dengan kondisi yang sedang berlangsung pada saat itu. Setiap orangtua melakukan pemeliharaan anak harus mmpertanggungjawabkan dan memperhatikan serta melakasanakan kewajiban sebagaimana semestinya peran orangtua, yang merupakan pemeliharaan terhadap hak-hak anaknya.

Hak anak diakui oleh hukum dan dilindungi oleh hukum sejak anak tersebut masih di dalam kandungan, serta hak anak juga merupakan hak asasi manusia sehingga untuk kepentingannya hak anak sangat diakui. Pada dasarnya anak tidak dapat melindungi dirinya sendiri dari berbagai tindakan yang dapat menimbulkan kerugian seperti kerugian mental, fisik maupun sosial yang terjadi di dalam kehidupan. Untuk itu seorang anak akan dibantu oleh orang lain untuk dapat melindungi dirinya dari tindakan yang dapat merugikan dirinya seperti yang telah disebutkan di atas tersebut. Anak wajib dilindungi agar anak tersebut tidak menjadi korban tindakan siapa saja (individu atau kelompok, organisasi swasta maupun pemerintah) baik itu langsung maupun tidak langsung. Yang dimaksud dengan korban adalah mereka yang menderita kerugian (mental, fisik, sosial) karena tindakan yang pasif maupun tindakan yang aktif orang lain atau kelompok (swasta atau pemerintah) baik langsung maupun tidak langsung. ${ }^{1}$

Sementara itu, sistem pidana bagi anak juga berbeda dengan sistem pidana dengan orang dewasa untuk itu sistem pidana bagi anak lebih memusatkan pada kepentingan anak yang menjadi unsur pusat perhatian dalam pengadilan terhadap anak. Untuk itulah undang-undang yang mengatur perlindungan terhadap anak tersebut sudah diatur dalam undang-undang yang telah ditetapkan. Perlindungan anak merupakan segala usaha yang dilakukan dalam menciptakan kondisi supaya setiap anak dapat melaksanakan hak dan kewajibannya demi perkembangan serta pertumbuhan anak baik fisik, mental maupun sosial. Kegiatan dalam perlindungan tersebut membawa akibat hukum, berkaitan dengan hukum tertulis maupun hukum tidak tertulis. ${ }^{2}$ Hal demikian sejalan dengan Konstitusi Republik Indonesia yang terdapat di dalam Pasal 28B ayat (2) Undang-Undang Dasar Negara Republik Indonesia Tahun 1945. ${ }^{3}$ Perlindungan terhadap anak tersebut juga berkaitan dengan hak asasi manusia untuk itu TAP MPR Nomor XVII/MPR/1998 yaitu mengenai Hak Asasi

Arif Gosita, Masalah Perlindungan Anak, Jakarta: Akademi Presindo, 1989, hlm. 35.

2 Maidin Gultom, Perlindungan Hukum terhadap Anak dalam Sistem Peradilan Anak di Indonesia, Bandung: Refika Utama, 2010, hlm. 33.

3 Pasal 28 b Ayat (2) Undang-Undang Dasar Negara Republik Indonesia Tahun 1945 berbunyi: "Hak anak untuk kelangsungan hidup, tumbuh dan berkembang serta hak atas perlindungan dari kekerasan dan diskriminasi". 
Manusia menyatakan bahwa pemahaman HAM bagi bangsa Indonesia adalah sebagai berikut: ${ }^{1}$

"Hak Asasi adalah hak dasar seluruh umat manusia tanpa ada perbedaan. Mengingat hak dasar merupakan anugrah dari Tuhan Yang Maha Esa, maka pengertian hak asasi manusia adalah hak sebagai anugerah Tuhan Yang Maha Esa yang melekat pada diri manusia sendiri ang bersifat kodrati dan abadi serta berkaitan dengan harkat dan martabat." Perlindungan HAM ini juga termasuk dalam konsep perlindungan terhadap anak dari berbagai tindak kekerasan dan kejahatan. Namun faktanya, berbagai tindak kekerasan terhadap anak terus terjadi dari hari ke hari, mulai dari eksploitasi hingga perdagangan anak. Komisi Perlindungan Anak Indonesia (KPAl) mencatat memasuki awal tahun 2018 ada sebanyak 32 kasus trafficking atau perdagangan manusia dan eksploitasi yang dialami oleh anak-anak di Indonesia. ${ }^{5}$

Padahal, perdagangan orang yang melibatkan anak sebagai korban perdagangan telah diatur secara jelas dalam Undang-Undang nomor 21 Tahun 2007 tentang Pemberantasan Tindak Pidana Perdagangan Orang, mulai dari Pasal 1 angka 5, Pasal 5, Pasal 6, Pasal 17, Pasal 38, Pasal 39, dan Pasal 40. Dalam hal tersebut ada beberapa hal yang perlu diperhatikan dalam perlindungan anak terhadap hukum pidana di Indonesia termasuk ke dalam konsepsi penyebab anak tersebut menjadi sosok yang melakukan tindak pidana yang berencana maupun yang dilatarbelakangi dengan sistem lingkungan yang memebentuk karakter yang tidak sesuai dengan karakter yang terdidik.

\section{Pembahasan}

\subsection{Faktor Penyebab Kejahatan pada Anak}

Anak sebagai pelaku tindak pidana membutuhkan perhatian dan penanganan khusus, juga dalam hal perlindungan bagi anak. Meskipun anak melakukan tindak pidana, mekanisme peradilan anak diatur secara khusus dan berbeda. Secara umum, berikut ini faktor-faktor penyebab anak melakukan tindak pidana.

\section{a. Teori Motivasi}

Seorang anak melakukan ssesuatu yang dianggap melanggar hukum yang berlaku bukan karena tidak ada sebab atau sesuatu hal yang tidak memiliki latar belakang untuk itu motivasi adalah salah satu seorang anak dapat melakuka tindak kejahatan yang pada dasarnya semua warga Negara Indonesia mengetahui bahwa hal tersebut tidak sesuai dengan hukum atau aturan yang berlaku di Indonesia pada saat ini. Menurut Kamus Besar Bahasa Indonesia (KBBI) yang dimaksud dengan motivasi merupakan dorongan yang timbul pada diri manusia secara sadar ataupun tidak sadar yang dilakukan dengan perbuatan tertentu dan juga tujuan tetentu. Untuk itu motivasi juga sering diartikan sebagai usaha yang menyebabkan seseorang atau kelompok tergerak untuk melakukan sesuatu yang ingin dicapainya dengan tujuan tertentu sehingga mendapat kepuasan yang dianggap dipenuhinya dengan perbuatannya. ${ }^{6}$

\section{b. Faktor Usia}

Faktor usia adalah faktor yang tidak dapat dipisahkan dari kejahatan karena pada dasarnya kejahatan akan mucul sesuai dengan usia dan tidak

4 Majelis Pemusyawaratan Rakyat Republik Indonesia, Putusan Majelis Permusyawaratan Rakyat Republik Indonesia: Sidang Tahunan Majelis Pemusyawaratan Rakyat Republik Indonesia 7-8 Agustus 2000. Sekretariat Jenderal MPR-RI: Jakarta.2000, hlm. 90 Bab I, Subbab D. Dikutip dari: Satya Arinanto, Hak Asasi Manusia dalam Transisi Politik di Indonesia, Jakart, Pusat Studi Hukum Tata Negara Fakultas Hukum Universitas Indonesia, 2011, hlm. 52.

5 Chyntia Sami Bhayangkara, Ada 32 Kasus Trafficking dan Eksploitasi Anak di Indonesia pada Awal 2018, OKEZONE NEWS, 3 April 2018, diakses dari https://news.okezone.com/read/2018/04/03/337/1881471/ada-32-kasus-trafficking-dan-eksploitasi-anakdi-indonesia-pada-awal-2018.

6 Pusat Pembinaan dan Pengembangan Bahasa, Kamus Besar Bahasa Indonesia, Jakarta, Balai Pustaka, 1995, hlm. 176. 
menutup kemungkinan anak dapat melakukan tindakan yang melanggar hukum yang ada karena faktor usia bukanlah hal yang membatasi suatu tindakan yang dianggap telah melanggar hukum. Sebab, pada faktanya narapidana juga bisa berumur usia muda yang dianggap memang sudah melanggar hukum dan tidak bisa ditoleransi lagi tindakan yang dilakukan. Contoh kejahatankejahatan yang dilakukan seorang anak di bawah umur penggunaan ganja yang dianggap telah melanggar hukum yang berlaku, selain itu adanya penggunaan sabu-sabu adanya kejahatan kesusilaan bahkan terdapat kejahatan pembunuhan. Hal tersebut dapat diperhatikan bahwasanya usia bukan lagi batasan dalam melakukan tindakan yang dianggap telah melanggar hukum dan hal tersebutlah yang dapat memicu kejahatan-kejahatan atau bahkan tindakan pidana lainya dapat terjadi pada seorang anak di bawah umur.

\section{c. Faktor Kelamin}

Faktor kelamin juga merupakan suatu faktor yang menyebabkan suatu tindakan pidana tersebut dapat terjadi pada anak usia di bawah umur. Paul W. Tappan mengemukakan bahwa kenakalan anak tersebut dapat dilakukan seorang anak laki-laki maupun anak perempuan walaupun pada umumnya jumlah anak laki-laki lebih banyak melakukan kejahatan daripada perempuan. Namun hal tersebut bukan berarti seorang anak perempuan tidak dapat melakukan kejahatan justru pada umumnya baik perempuan maupun laki-laki tetap melakukan kejahatan dengan tujuan masing-masing.

Pada dasarnya kejahatan yang dilakukan oleh banyak laki-laki adalah pencurian, perampokan, penganiayaan, pembunuhan, pemerkosaan dan lain sebagainya. Sedangkan pelanggaran yang dilakukan seorang perempuan adalah perbuatan melanggar peratutan umum, pelanggaran kesusilaan seperti melakukan persetubuhan di luar perkawinan sebagai akibat dari pergaulan yang bebas.

\section{d. Faktor Kedudukan Anak dalam Keluarga}

Pengertian dari hal tersebut adalah urutan kelahiran seorang anak dalam suatu keluarga, dan mengenai kedudukan anak tersebut dalam suatu keluarga. Hasil penelitian yang dilakukan oleh Noach terhadap kriminalitas di Indonesia dan telah dikemukakan bahwa kebanyakan kejahatan tersebut dilakukan oleh anak pertama dan anak tunggal atau oleh anak perempuan atau dia satu-satunya dari antara saudara-saudaranya (kakak maupun adiknya). Hal tersebut mudah untuk dipahami karena pada dasarnya anak tunggal adalah anak yang paling dimanjakan oleh orangtuanya sehingga pengawasan yang dilakukan sangat luar biasa, pemenuhan kebutuhan yang dilakukan dengan berlebih-lebih dan segala bentuk keinginan dapat dikabulkan oleh orangtua, hal tersebut yang menjadi pemicu timbulnya cenderung dan frustasi menimbulkan kejahatan yang dilakukan dalam suatu kemasyarakatan.

\section{e. Faktor Keluarga}

Keluarga merupakan suatu lingkungan yang dianggap sangat dekat dengan anak, untuk itu tempat pembentukan karakter pertama kali terdapat pada keluarga sendiri untuk itulah keluarga merupakan wadah pertama dalam pembentukan karakter seorang anak. Menurut Moelyatno, ${ }^{7}$ broken home menyebabkan anak sebagian besar melakukan kenakalan, terutama karena perceraian atau perpisahan orangtua yang sangat memenga-

Wagiati Soetodjo, Hukum Pidana Anak, Bandung: Refika Aditama, 2006, hlm.20. 
ruhi perkembangan pertumbuhan si anak dan di dalam broken home itu sendiri terdapat hal yang menyebabkan kenapa keluarga tersebut tidak lengkap lagi, di antaranya adalah:

1) Salah satu dari kedua orangtua si anak atau bahkan keduanya telah meninggal

2) Perceraian dari orangtua

3) Salah satu dari kedua orangtua tersebut tidak hadir secara kontinu dalam waktu yang cukup lama.

Dalam hal tersebut dapat ditarik suatu kesimpulan bahwa kenakalan seorang anak atau tindak pidana yang dilakukan pada dasarnya dipengaruhi oleh keluarga.

\subsection{Perlindungan Hukum pada Anak: Antara Sistem Penghukuman dan Hak Asasi Manusia}

Penjatuhan pidana terkhusus pidana penjara yang diberikan oleh hakim terhadap anak mengakibatkan jatuhnya hukuman terhadap anak yang melakukan perbuatan melawan hukum maka dengan itu pertimbangan dari petugas kemasyarakatan baik dari pembimbing kemasyarakatan itu sendiri ataupun dari Departemen Kehakiman, petugas dari kemasyarakatan dan Departemen Sosial serta petugas sukarela dari organisasi sosial kemasyarakatan tersebut. ${ }^{8}$ Fungsi dari petugas kemasyarakatan itu sendiri adalah sebagai orang yang memberikan laporan dari petugas kemasyarakatan melihat dari latar belakang baik sosial, keluarga serta ekonomi dari keluarga itu sendiri atau bahkan dari lingkungan anak nakal yang kasusnya masih atau sedang dalam proses peradilan pidana. Untuk itu penjatuhan hukuman terhadap anak dalam pemberlakuannya harus melihat berbagai pertimbangan dalam HAM yang mengikat serta adanya peran dari kemasyarakatan itu sendiri di dalam lingkup masyarakat untuk itulah sistem kemasyarakatan itu sangat berperan dalam pembimbingan terhadap anak yang dianggap telah melanggar aturan yang berlaku pada saat itu dan pada aturan yang sudah ditetapkan sejak awal dengan demikian kemasyarakatan sangat berperan aktif dibandingkan dengan hukuman pidana yang ditetapkan seperti penjara maupun kurungan.

Namun pada dasarnya hukuman tersebut memiliki sifat yang mendidik untuk itu dalam pemikiran seorang tokoh yang diambil dari M.J. Langeveld dalam bukunya Beknopte Theorishe Paedagogiek mengemukakan bahwa hukuman merupakan suatu perbuatan yang di mana kita secara sadar bahkan sengaja untuk menjatuhkan nestapa terhadap seseorang baik dari segi kejasmanian maupun dari segi kerokhaniannya, mempunyai berbagai kelemahan dan dampak baik bagi anak yang diberikan sanksi atau hukuman maupun bagi masyarakat.

Ada juga yang disebut sebagai pendekatan hukum progresif yang berangkat dari asumsi dasar bahwa "hukum untuk manusia, bukan manusia untuk hukum". Berangkat dari asumsi tersebut dasar tersebut kehadiran hukum itu bukanlah untuk diri hukum itu sendiri tetapi sesuatu yang lebih luas dan juga besar. Maka dari hal itu apabila suatu masalah di dalam suatu hukum, maka dari itu hukumlah yang harus lebih ditinjau dan diperbaiki terlebih dahulu, bukan manusia yang dipaksa untuk di masukkan ke dalam suatu skema hukum. ${ }^{9}$

\footnotetext{
8 Bambang Purnomo, Gunarto, "Penegakan Hukum Tindak Pidana Anak Sebagai Pelaku Dalam Sistem Peradilan Pidana Anak (Studi Kasus di Polres Tegal)", Jurnal Hukum Khaira Ummah Vol. 13. No. 1 Maret 2018, hlm 46.

9 Satjipto Rahardjo, "Hukum Progresif: Hukum yang Membebaskan", Jurnal Hukum Progresif, Volume 1/ No. 1/April 2005, Program
} Doktor Ilmu Hukum UNDIP, hlm. 5. 
Bahkan, penahanan terhadap anak juga pada dasarnya bisa dihindarkan ataupun dibatasi terhadap keadaan tertentu yang luar biasa (limited to exceptional circumtances) dan apabila perlu diupayakan alternatif-alternatif lain yang dapat dilakukan. Namun demikian, jika dilakukan penahanan terhadap anak, maka terdapat beberapa hal yang perlu diperhatikan seperti:

1) penahanan yang dilakukan dengan sesingkat mungkin (the shortest duration of detention);

2) penahanan tersebut dipisahkan dengan anak-anak yang telah terlebih dahulu dipidana (be separated from convicted juveniles)

3) diperbolehkan dalam meminta bantuan hukum (free legal aid);

4) privasi dan kerahasiaan harus tetap dijamin (privacy and confidentiality shall be ensured);

5) disediakan kesempatan bekerja, sekolah maupun pelatihan, asalkan hal tersebut tidak sebagai alasan dalam perpanjangan penahanan (be provided, where posible, opportunities to pursue work, and continue education or training, not cause the continuation of the detention). ${ }^{10}$

Istilah sistem peradilan pidana anak adalah terjemahan dari istilah The Juvenile Justice System, yaitu suatu istilah yang dapat digunakan oleh beberapa institusi yang tergabung dalam pengadilan, meliputi polisi, jaksa penuntut umum dan penasehat hukum, serta lembaga pengawasan, pusat-pusat penahanan anak, dan terakhir adalah fasilitas-fasilitas pembinaan anak. ${ }^{11}$

Di atas hal tersebut terdapat juga hak-hak atas anak itu sendiri yaitu berdasarkan Konvensi Hak-Hak Anak, hak-hak anak secara umum dapat digolongkan kedalam 4 (empat) kategori, diantaranya adalah: ${ }^{12}$

a. Hak untuk kelangsungan hidup (The Right to Survival), yaitu dalam hak-hak tersebut agar dapat melestarikan dan mempertahankan hidup (The Right of Live) dan hak memperoleh standar kesehatan tertinggi serta perawatan yang baik.

b. Hak terhadap perlindungan (Protections Rights) yaitu dalam konvensi hak anak yang meliputi hak dalam perlindungan baik itu dari diskriminasi, tindak kekerasan serta keterlantaran bagi anak yang merupakan seseorang yang tidak mempunyai keluarga bagi anak-anak pengungsi.

c. Hak untuk tumbuh kembang (Development Rights) yaitu hak anak dalam Konvensi Hak-Hak Anak yang terdiri dari hak bentuk pendidikan (formal dan nonformal) dan hak untuk mencapai standar hidup yang layak dan

10 United Nation Rules for the Protection of Juveniles Deprived of their liberty. Adopted by Assembly resolution 45/113 of 14 December 1990. Artikel 17; lihat juga Angga, A., \& Arifin, R. Penerapan Bantuan Hukum Bagi Masyarakat Kurang Mampu di Indonesia. DIVERSI: Jurnal Hukum, Vol. 4 No. 2, 2019, hlm. 218 - 236. DOI: 10.32503/diversi.v4i2.374

11 The Juvenile Justice System sebagaimana digunakan SMRJJ - The Beijing Rules yang tertera dalam Rule 5.1. Lihat pula Joan Mc. Cord dan kawan-kawan. Joan Mc. Cord, Cathy Spatz Widom, and Nancy A. Crowell, eds., 2001, Juvenile Crime, Juvenile Justice. Panel on Juvenile Crime: Prevention, Treatment, and Control, National Academy Press, Washington DC, hIm. 154. Dalam buku tersebut disebutkan: "term juvenile justice is often used synonymously in addition to the court, but it also may refer to other affiliated institutions in addition to the court, including the police, prosecuting and defence attorney, probation, juvenile detention centers, and juvenile correctional facilities"

12 Mohammad Joni dan Zulchaina Z. Tanamas, Aspek Hukum Perlindungan Anak dalam Perspektif Konvensi Hak Anak, Bandung, Citra Aditya Bakti, 1999, hlm. 35. 
baik bagi perkembangan fisik, mental, spiritual, moral dan sosial anak (the rights of standart of living).

d. Hak untuk berpartisipasi (Participation Rights), yaitu hak anak yang terdiri dari hak untuk menyatakan pendapat mereka dalam segala hal yang mempengaruhi anak (the rights of a child to express her/his views freely in all matters affecting the child).

Di dalam Black's Law Dictionary, disebutkan mengenai diversi yaitu sebagai Divertion dan Divertion Program. Divertion itu sendiri yaitu: " $A$ turning a side or altering the natural course or route of a thing. The term is chiefly applied to the an authorized change and alteration of the water course to the prejudice of a lower reparian, or the authorized use of funds."13 Kemudian Selanjutnya Divertion Program, di dalam Black's Law Dictionary, dikatakan bahwa: "A disposition of a criminal defendant either before or after adjudication of guilt in which the court directs the defendant to participate in a work or educational program as part of probation". Untuk melaksanakan diversi tersebut maka dibutuhkan suatu perbuatan yang dilakukan berdasarka hukum yang sudah berlaku.

Anak sebagai bagian dari generasi penerus bangsa dan generasi muda merupakan suatu mata rantai awal yang sangat penting dan sangat menentukan dalam upaya terhadap persiapan dalam mewujudkan masa depan bangsa dan negara. Anak juga merupakan generasi muda dan generasi bangsa yang akan meneruskan perjuangan serta cita-cita seluruh bangsa di belahan bumi ini. Hal ini secara tegas dirumuskan dalam butir Konsiderans
Undang-Undang Nomor 35 Tahun 2014 mengenai Perubahan Atas Undang-Undang Nomor 23 Tahun 2002 Tentang Perlindungan Anak yang berbunyi: "bahwa anak adalah sebuah tunas, potensi, dan generasi muda sebagai penerus cita-cita perjuangan bangsa, memiliki peran dan fungsi strategis dan mempunyai ciri serta sifat khusus yang akan menjamin kelangsungan eksistensi bangsa dan negara pada masa depan. ${ }^{14}$

Berkaitan dengan perlindungan anak, karena anak sebagai generasi penerus dalam keluarga dan menjadi estafet untuk menjamin kelangsungan eksistensi bangsa, sama halnya yang ada pada butir c UU. No. 23 Tahun 2002 tentang Perlindungan Anak. Pada masa depan anak adalah tunas, potensi, dan generasi muda penerus cita-cita perjuangan bangsa, memiliki peran strategis dan mempunyai ciri dan sifat khusus yang menjamin kelangsungan eksistensi bangsa dan negara. Anak juga menjadi tunas bangsa yang harus dilindungi hidup dan penghidupanya lalu menjadi tanggungjawab orangtua, keluarga, masyarakat serta neraga. Sebagai generasi penerus, anak-anak harus lah menjadi individu yang dapat dipersiapkan dengan matang untuk masa depannya, namun seiring perubahan jaman, dan perubahan sosial memiliki dampak yang sungguh uar biasa dalam perubahan yang terjadi permasalahan anak berupa penelantaran, eksploitasi, perdagangan anak, diskriminasi, kekerasan terhadap anak baik fisik, psikis dan seksual. Kebutuhan tentang perlindungan anak sangat dibutuhkan agar kondis anak dapat bertahan dalam dunia yang semakin keras. ${ }^{15}$

Hunter sebagaimana dikutip Gosita (2013) menyebutkan bahwa ada 80\% korban sexual abuse

13 Henry Campbell Black, Black's Law Dictionary, St. Paul Minn West Publicing Co., Sixth Edition, 1990, hlm. 477.

14 Anonimous, UU Perlindungan Anak, UU No. 35 Tahun 2014 tentang Perubahan Atas UU No. 23 Tahun 2002 tentang Perlindungan Anak, Pustaka Mahardika, Yogyakarta, 2015, hlm. 2.

15 Tateki Tursilani, "Dampak Kekerasan Seksual di Ranah Domestik Terhadap Keberlangsungan Hidup Anak", Jurnal Media Informasi Penelitian Kesejahteraan Sosial, Vol. 41, No. 1, 2017. 
pelakunya merupakan laki-laki dan $90 \%$ pengalaman seksual melibatkan korban yang masih belum dewasa. Ada kompleksitas yang terlibat dalam penelitian tentang masalah sexual yang dialami anak-anak, lalu untuk korban dengan usia dewasa tidak banyak dilaporkan dibanding dengan kasus pelecehan anak. ${ }^{16}$ Pendidikan yang diberikan seperti memberi informasi apa fungsi kelamin pada perempuan dan laki-laki, dan seperti organ-organ tertentu harus selalu ditutup dan dijaga dari pandangan orang lain. ${ }^{17}$ Pasal 1 Ayat 2 UndangUndang Nomor 23 Tahun 2002 tentang Perlindungan Anak menentukan bahwa perlindungan anak adalah segala kegiatan untuk menjamin dan melindungi anak dan hak-haknya agar dapat hidup, tumbuh, berkembang, dan berpartisipasi, secara optimal sesuai dengan harkat dan martabat kemanusiaan, serta mendapat perlindungan dari kekerasan dan diskriminasi. ${ }^{18}$

Bahkan, bentuk-bentuk kekerasan yang terjadi terhadap anak banyak sekali termasuk di dalamnya adalah bentuk kekerasan fisik, ${ }^{19}$ kekerasan psikis/emosional dan kekerasan seksual, diantaranya berupa: dicubit, didorong, digigit, dicekik, ditendang, disiram, ditempeleng, disuruh push-up, disuruh lari, mengancam, diomeli, dicaci, diludahi, digunduli, diusir, dipaksa bersihkan wc, dipaksa mencabut rumput, dirayu, dicolek, kekerasan seksual, diperkosa dan lain sebagainya. Bahwa sangatlah penting untuk mengatur perlindungan bagi dan terhadap korban kejahatan terlebih lagi anak yang merupakan seorang korban yang sangat rentan terutama bagi perempuan ${ }^{20}$ perlindungan ini telah diatur di dalam peraturan perundangundangan yang di dalamnya telah diatur perihal perlindungan korban kejahatan secara komprehensif, seperti perlindungan fisik, finansial, psikis maupun medis dan yang lebih terpenting adalah bahwa perlindungan tersebut ditujukan pada korban kejahatan yang merupakan korban yang terdiri dari semua jenis kejahatan. Seperti yang sudah tertulis di dalam UU No. 23 Tahun 2002 tentang Perlindungan Anak yang telah diubah dengan UU No. 35 Tahun 2014, UU No. 15 Tahun 2003 tentang Tindak Pidana Terorisme, UU No. 31 Tahun 2014 tentang Perubahan Atas UU No. 13 Tahun 2006 tentang Perlindungan Saksi dan Korban.

Padahal, perlindungan terhadap anak bukan hanya diatur oleh berbagai peraturan perundang-undangan, namun juga menjadi kewajiban masyarakat, individu, pemerintah dan negara sebagaimana diamanatkan oleh undangundang. Berbagai perilaku menyimpang yang ada saat ini juga terjadi akibat dari perubahan sosial di masyarakat dan berbagai perkembangan dinamika penegakan hukum. Sehingga, penting menghadirkan konsep keadilan yang jelas dalam penanganan permasalahan anak yang berhadapan dengan hukum sehingga ukuran keadilan tersebut dapat memberikan setiap orang terhadap apa yang menjadi haknya. Salah satu tujuan hukum yaitu mewujudkan keadilan. Hal ini juga bersangkutan dengan tiga tujuan hukum yaitu kepastian hukum,

16 Harjo, Novita, "Hubungan Dukungan Sosial Dengan Psychological Well-Being Pada Remaja Korban Sexual Abuse". Jurnal Analitika, Vol. 7, No. 1, 2017, hlm. 15

17 Risty Justicia, "Program Underwear Rules Untuk Mencegah Kekerasan Seksual Anak Usia Dini", Jurnal Pendidikan Usia Dini, Vol. 9, No. 2, 2016, hlm. 222

18 Setyaningrum, A. \& Arifin, R., "Analisis Upaya Perlindungan dan Pemulihan Terhadap Korban Kekerasan dalam Rumah Tangga (KDRT) Khususnya Anak-Anak dan Perempuan", MUQODDIMAH: Jurnal IImu Sosial, Politik, dan Humaniora, Vol. 3 No. 1, 2019.

19 Endre Vendy Katiandagho, "Perlindungan Hukum Terhadap Anak Sebagai Korban Kejahatan Menurut Hukum Pidana Indonesia", Lex Crimen Vol. V No. 6, Agustus 2016, hlm. 82-83

20 Kemala Dewi, M., \& Arifin, R., "Emancipation and Legal Justice: Portrait of Women's Legal Protection in Indonesia", JURNAL CITA HUKUM, Vol. 7 No. 1, 2019, DOl: https://doi.org/10.15408/jch.v7i1.10261 
kemanfaatan hukum dan keadilan hukum. ${ }^{21}$ Sehingga hal tersebut berkaitan dengan hukum pidana atas perlindungan anak di Indonesia.

\section{Kesimpulan}

Konsep perlindungan pada anak dalam kerangka hak asasi manusia dan hukum pidana di Indonesia termuat dalam berbagai undang-undang. Berbagai definisi dan batasan anak juga diatur secara jelas tidak hanya dalam Undang-Undang Perlindungan Anak, namun juga undang-undang yang lainnya. Pola-pola kejahatan yang dilakukan anak seringkali menimbulkan ambigiutas dalam penegakan hukum, apakah anak melakukan kenakalan anak atau remaja (Juvenile Delinquency) ataukah sudah melakukan tindak pidana. Dalam banyak kasus, anak-anak terlibat dalam berbagai tindak pidana berat dan mendapatkan sanksi pidana sebagaimana orang dewasa. Berbagai faktor penyebab anak melakukan tindak pidana dan kejahatan, diantaranya, faktor keluarga, lingkungan, dan pengaruh sosial masyarakat serta usia. Selain itu, motivasi dan perubahan perilaku masyarakat ikut mempengaruhi pola-pola kejahatan yang dilakukan oleh anak.

\section{DAFTAR PUSTAKA}

\section{A. Buku}

Arinanto, Satya. Hak Asasi Manusia dalam Transisi Politik di Indonesia. Jakarta: Pusat Studi Hukum Tata Negara Fakultas Hukum Universitas Indonesia, 2011.

Azizah, Nur. Nilai Keadilan Terhadap jaminan Kompensasi Bagi Korban Kejahatan (Sebuah Kajian Filosofis - Normatif. Makassar: Pustaka Pena Press, 2016.

Black, Henry Campbell. Black's Law Dictionary. St. Paul Minn West Publishing Co., Sixth Edition, 1990.

Gosita, Arif. Masalah Perlindungan Anak. Jakarta: Akademi Presindo, 1989.

Gultom, Maidin. Perlindungan Hukum terhadap Anak dalam Sistem Peradilan Anak di Indonesia. Bandung: Refika Utama, 2010.

Joan Mc. Cord, Cathy Spatz Widom, and Nancy A. Crowell, eds. Juvenile Crime, Juvenile Justice. Panel on Juvenile Crime: Prevention, Treatment, and Control. Washington DC: National Academy Press, 2001.
Joni, Mohammad dan Zulchaina Z. Tanamas. Aspek Hukum Perlindungan Anak dalam Perspektif Konvensi Hak Anak. Bandung: Citra Aditya Bakti, 1999.

Limantoro, Singgih Widodo. "Hukuman Sebagai Alat Pendidikan Ditinjau Dari Sudut Pandang Pendidikan, Hukuman, Agama, dan Medika", Jurnal Teknologi Pembelajaran: Teori dan Penelitian, Tahun 8, Nomor 2, Oktober 2000.

Majelis Pemusyawaratan Rakyat Republik Indonesia. Putusan Majelis Permusyawaratan Rakyat Republik Indonesia: Sidang Tahunan Majelis Pemusyawaratan Rakyat Republik Indonesia 7-8 Agustus 2000.

Sekretariat Jenderal MPR-RI: Jakarta. 2000.

Pusat Pembinaan dan Pengembangan Bahasa. Kamus Besar Bahasa Indonesia. Jakarta: Balai Pustaka, 1995.

Soetodjo, Wagiati. Hukum Pidana Anak. Bandung; Refika Aditama, 2006.

\section{B. Jurnal}

Angga, A., \& Arifin, R. Penerapan Bantuan Hukum Bagi Masyarakat Kurang Mampu di Indonesia.

21 Nur Azizah, 2016, Nilai Keadilan Terhadap jaminan Kompensasi Bagi Korban Kejahatan (Sebuah Kajian Filosofis - Normatif), Pustaka Pena Press, Makasar, hlm. 23, lihat juga Putri, K. D. A., \& Arifin, R., "Tinjauan Teoritis Keadilan dan Kepastian dalam Hukum di Indonesia (The Theoretical Review of Justice and Legal Certainty in Indonesia)". MIMBAR YUSTITIA, Vol. 2 No. 2, 2019, hlm. 142-158. Arifin, R, Rasdi, R, Alkadri, R. "Tinjauan atas Permasalahan Penegakan Hukum dan Pemenuhan Hak dalam Konteks Universalime dan Relativisme Hak Asasi Manusia di Indonesia", LEGALITY: Jurnal IImiah Hukum, Vol. 26 No. 1, 2018 
DIVERSI: Jurnal Hukum, Vol. 4 No. 2, 2019, hlm. 218 - 236. DOI: 10.32503/diversi.v4i2.374

Arifin, R, Rasdi, R, Alkadri, R. "Tinjauan atas Permasalahan Penegakan Hukum dan Pemenuhan Hak dalam Konteks Universalime dan Relativisme Hak Asasi Manusia di Indonesia", LEGALITY: Jurnal IImiah Hukum, Vol. 26 No. 1, 2018

Harjo, Novita. "Hubungan Dukungan Sosial Dengan Psychological Well-Being Pada Remaja Korban Sexual Abuse". Jurnal Analitika, Vol. 7, No. 1, 2017.

Justicia, Risty. "Program Underwear Rules Untuk Mencegah Kekerasan Seksual Anak Usia Dini", Jurnal Pendidikan Usia Dini, Vol. 9, No. 2, 2016.

Katiandagho, Endre Vendy. "Perlindungan Hukum Terhadap Anak Sebagai Korban Kejahatan Menurut Hukum Pidana Indonesia", Lex Crimen Vol. V No. 6, Agustus 2016.

Kemala Dewi, M., \& Arifin, R., "Emancipation and Legal Justice: Portrait of Women's Legal Protection in Indonesia", JURNAL CITA HUKUM, Vol. 7 No. 1, 2019, DOI: https://doi.org/10.15408/jch.v7i1.10261

Noviana, Ivo. "Child Sexual Abuse: Impact and Hending", Sosio Informa, Vol. 01, No. 1, 2015 , hlm. 17-28.

Purnomo, Bambang dan Gunarto, "Penegakan Hukum Tindak Pidana Anak Sebagai Pelaku Dalam Sistem Peradilan Pidana Anak (Studi Kasus di Polres Tegal)", Jurnal Hukum Khaira Ummah Vol. 13. No. 1 Maret 2018.

Putri, K. D. A., \& Arifin, R., "Tinjauan Teoritis Keadilan dan Kepastian dalam Hukum di Indonesia (The Theoretical Review of Justice and Legal Certainty in Indonesia)". MIMBAR YUSTITIA, Vol. 2 No. 2, 2019.

Satjipto Rahardjo, "Hukum Progresif: Hukum yang Membebaskan", Jurnal Hukum Progresif, Volume 1 No. 1, April 2005.

Setyaningrum, A. \& Arifin, R., "Analisis Upaya Perlindungan dan Pemulihan Terhadap Korban Kekerasan dalam Rumah Tangga (KDRT) Khususnya Anak-Anak dan Perempuan", MUQODDIMAH: Jurnal IImu Sosial, Politik, dan Humaniora, Vol. 3 No. 1, 2019.

Tursilani, Tateki. "Dampak Kekerasan Seksual Di Ranah Domestik Terhadap Keberlangsungan Hidup Anak", Jurnal Media Informasi Penelitian Kesejahteraan Sosial, Vol. 41, No. 1, 2017.

\section{Internet}

Bhayangkara, Chyntia Sami, Ada 32 Kasus Trafficking dan Eksploitasi Anak di Indonesia pada Awal 2018, OKEZONE NEWS, 3 April 2018, diakses dari https://news.okezone.com/read/2018/04/03/337 /1881471/ada-32-kasus-trafficking-daneksploitasi-anak-di-indonesia-pada-awal-2018

\section{Peraturan Perundang-undangan}

Undang-Undang Dasar Negara Republik Indonesia Tahun 1945

United Nation Rules for the Protection of Juveniles Deprived of their liberty. Adopted by Assembly resolution 45/113 of 14 December 1990. Artikel 17.

Undang-Undang Perlindungan Anak, UU No. 35 Tahun 2014 tentang Perubahan Atas UU No. 23 Tahun 2002 tentang Perlindungan Anak. 